\title{
Blends of hard coal sludge with pulverized lignite as alternative energy raw materials
}

ABSTRACT: Hard coal sludge is classified as group 01 waste or it is a by-product in the production of a hard coal with variable energy importance. Pulverized lignite is not waste but a final product of drying and the very fine pulverization of lignite with a high calorific value. The study comprised the basic material before granulation such as coal sludge (PG SILESIA) and pulverized lignite (LEAG) as well as their prepared blends after the granulation on a pipe vibration granulator designed at AGH. The pulverized lignite of the LEAG company shows a low sulfur contents. In the analyzed samples its average content $\left(\mathrm{S}_{\text {tot }}{ }^{\mathrm{d}}\right)$ is $0.61 \%$. An average value of this parameter in the analyzed coal sludge samples is $0.55 \%$. The addition of pulverized lignite does not have a significant impact on the total content of sulfur and of analyzed toxic elements $(\mathrm{Hg}, \mathrm{As}, \mathrm{Cd}, \mathrm{Cr}, \mathrm{Co}, \mathrm{Cu}, \mathrm{Mn}, \mathrm{Ni}, \mathrm{Pb}, \mathrm{Sb}, \mathrm{Tl}$, and $\mathrm{W}$ ) in the samples. The calorific value of coal sludge falls within the range of $11.0-12.4 \mathrm{MJ} / \mathrm{kg}$ (on a dry basis). For the coal sludge and pulverized lignite blends the calorific value clearly increases to values of $14.8-17.7 \mathrm{MJ} / \mathrm{kg}$ (on dry basis). The calorific value slightly decreases in the

$\triangle$ Corresponding Author: Beata Klojzy-Karczmarczyk; e-mail: beatakk@min-pan.krakow.pl

1 Mineral and Energy Economy Research Institute of the Polish Academy of Sciences, Kraków, Poland; ORCID iD: 0000-0002-2003-2291; e-mail: beatakk@min-pan.krakow.pl

2 Mineral and Energy Economy Research Institute, Polish Academy of Science, Kraków, Poland; ORCID iD: 00000002-8746-0282; e-mail: jan@min-pan.krakow.pl

3 EP Coal Trading Polska S.A. Czechowice-Dziedzice, Poland; e-mail: marek.wiencek@epcoaltrading.pl

4 AGH University of Science and Technology, Kraków, Poland; ORCID iD: 0000-0002-5653-1674; e-mail: feliks@ agh.edu.pl

2019. The Author(s). This is an open-access article distributed under the terms of the Creative Commons Attribution-ShareAlike International License (CC BY-SA 4.0, http://creativecommons.org/licenses/by-sa/4.0/), which permits use, distribution, and reproduction in any medium, provided that the Article is properly cited. 
case of granulation with the $\mathrm{CaO}$ additive. Such values increase the possibilities of application in the commercial power sector. It is possible to state that all sludge and pulverized lignite blends are susceptible to granulation. The drop strength of the fresh pellets is satisfactory and the averaged value is around 4. After seasoning the drop strength of blends definitely falls, on average by $30 \%$, except for pellets made of pure coal sludge. So the addition of pulverized lignite hinders the possibilities of granulation as compared with pure coal sludge.

KEYWORDS: coal sludge (of hard coal), pulverized lignite (coal dust from lignite), granulation, quality parameters, calorific value

\section{Introduction}

The combustion and offering on the retail market of a fuel such as coal sludge and lignite was limited by the Act of July 5, 2018 on the Amendment to the Act on Fuel Quality Monitoring and Controlling and to the Act on the National Tax Administration (Journal of Law 2018, item 1654). The adopted and planned regional parliament resolutions of many provinces also integrate with the provisions of this law and the fight against low-stack emission in Poland (Stala-Szlugaj 2018a, 2018b). Hard coal sludge referred in the paper to as sludge or coal sludge is an inseparable by-product of hard coal production. It frequently features a low calorific value. Coal sludge is classified as waste with code 010412 and 010481 or it is a by-product in the production of raw materials with limited energy importance. Because of the withdrawal of coal sludge from trading on the municipal market, its amount offered for sales by mines for commercial customers will be growing. The combustion and offering on the retail market of a fuel such as lignite was also limited by the provisions of the aforementioned law. Pulverized lignite is not a waste but a final product of drying and the next very fine pulverization of lignite. It features a high calorific value, it is used in district heating plants and power plants, in many sectors of industry, including: cement plants, lime plants, drying plants, or bituminous material factories as basic or alternative fuel to heating oil (https://www.lignoplus.de/; https://www.epcoaltrading.cz/pl/). Due to its properties, under specified conditions it is an explosive, due to which it is classified as a hazardous material.

As a result of new legislation it is necessary to look for new solutions to manage both materials. Possible solutions include the energy use of coal sludge in various blends or reclamation of degraded areas and using it for landfills sealing (Klojzy-Karczmarczyk and Mazurek 2017). Preliminary studies, carried out in 2018, have shown that as a result of blending coal sludge with pulverized lignite and of such material granulating it is possible to manufacture a product of appropriate quality and physical parameters with a clear improvement in energy parameters. Results of qualitative tests were the subject of paper by B. Klojzy-Karczmarczyk, J. Mazurek and M. Wiencek (Klojzy-Karczmarczyk et al. 2018), while results of studies on transportablity of the obtained material are the subject of paper by J. Feliks, B. Klojzy-Karczmarczyk, and M. Wiencek (Feliks et al. 2018). The coal sludge analyzed in the quoted papers and used to 
prepare samples originated from PG SILESIA. Instead, the pulverized lignite is a mixture of materials from various suppliers (the company LEAG is not the producer, as mistakenly stated in the quoted papers content).

The presented paper is aimed at carrying out the next studies to find a method to increase the attractiveness of coal sludge as a fuel for commercial customers. The essence of the solution consists in increasing the calorific value of the coal sludge by the pulverized lignite additions and improving its transport properties as a result of granulation. In the 2018 study the pulverized coal used for tests featured an increased sulfur content of approx. 1.5\% (no clear identification by the producer). In the next study pulverized lignite from LEAG with a low and stable sulfur content on a long-period average of $0.7 \%$ was used for energy enrichment of coal sludge (https://www. lignoplus.de/). A similar research methodology was used as in the papers quoted above (Klojzy-Karczmarczyk et al. 2018; Feliks et al. 2018). The obtained product may be interesting for commercial coal customers, which would undoubtedly translate into its commercial attractiveness and would become a new method to manage the coal sludge and pulverized lignite. At this stage of work the Authors have not considered the cost aspect of the analyzed project.

\section{Samples preparation for tests}

Tests and analysis comprised samples of the basic material: coal sludge and pulverized lignite and blends prepared from basic components without a binder and with addition of a binder, which is $\mathrm{CaO}$ (Table 1). The topic consideration results from the consultation with representatives of the EP Coal Trading Polska S.A., a company belonging to the EPH, a.s. Capital Group. In its structures, this Group owns the PG SILESIA hard coal mine, from which the coal sludge designed for tests originates. The pulverized lignite producer, which was designed for energy enrichment of the coal sludge, in this case is the LEAG company (Germany).

The basic test material was analyzed (Table 2):

$\checkmark$ coal sludge from hard coal mining (after passing through filter presses) - taken in February 2018 (sludge 1) and in March 2019 (sludge 2);

$\downarrow$ pulverized lignite - originating from direct production (3 samples taken in weekly intervals in March 2019: dust 1, dust 2, dust 3).

Individual substrates (basic material) were blended in an air-dry condition in accordance with percentage shares declared in the table (Table 2). Samples prepared without the binder were named 1 to 7 , while with the binder's addition (of approx. 3\%) - 1a to 7a. All the samples were analyzed for quality parameters after the carried out granulation. 
TABLE 1. Specification of coal sludge with pulverized lignite blend samples designed for laboratory tests (after granulation)

TABELA 1. Zestawienie próbek mieszanek mułów węglowych z pyłami z węgla brunatnego wykorzystanych do badań laboratoryjnych (po procesie granulowania)

\begin{tabular}{|c|c|}
\hline Sample number and name & $\begin{array}{c}\text { Planned percentage composition of substrates in individual blends intended } \\
\text { for granulation and quality parameters analysis }\end{array}$ \\
\hline $\begin{array}{c}\text { Sample No. } 1 \text { and } 1 \mathrm{a} \\
\text { sludge } 1+\text { dust } 1\end{array}$ & Coal sludge $1(50 \%)+$ pulverized lignite $1(50 \%)$ \\
\hline $\begin{array}{c}\text { Sample No. } 2 \text { and } 2 \mathrm{a} \\
\text { sludge } 2+\text { dust } 1\end{array}$ & Coal sludge $2(50 \%)+$ pulverized lignite $1(50 \%)$ \\
\hline $\begin{array}{c}\text { Sample No. } 3 \text { and } 3 \mathrm{a} \\
\text { sludge } 1+\text { dust } 2\end{array}$ & Coal sludge $1(50 \%)+$ pulverized lignite $2(50 \%)$ \\
\hline $\begin{array}{c}\text { Sample No. } 4 \text { and } 4 \mathrm{a} \\
\text { sludge } 2+\text { dust } 2\end{array}$ & Coal sludge $2(50 \%)+$ pulverized lignite $2(50 \%)$ \\
\hline $\begin{array}{c}\text { Sample No. } 5 \text { and } 5 \mathrm{a} \\
\text { sludge } 1+\text { dust } 3\end{array}$ & Coal sludge $1(50 \%)+$ pulverized lignite $3(50 \%)$ \\
\hline $\begin{array}{c}\text { Sample No. } 6 \text { and } 6 a \\
\text { sludge } 2+\text { dust } 3\end{array}$ & Coal sludge $2(50 \%)+$ pulverized lignite $3(50 \%)$ \\
\hline $\begin{array}{c}\text { Sample No. } 7 \text { and } 7 \mathrm{a} \\
\text { sludge } 2\end{array}$ & Coal sludge 2 \\
\hline
\end{tabular}

Samples marked ' $\mathrm{a}$ ' - with the addition of $\mathrm{CaO}(3 \%)$

Origin of the material: coal sludge from hard coal mining - PG SILESIA; pulverized lignite (coal dust from lignite) - LEAG - Germany.

Substrates were blended in the air-dry condition.

\section{Qualitative analysis of the basic material and of blends}

\subsection{Applied methodology}

Based on the literature data (Bielowicz 2013; Makowska et al. 2017) 12 toxic elements were selected ( $\mathrm{Hg}, \mathrm{As}, \mathrm{Cd}, \mathrm{Cr}, \mathrm{Co}, \mathrm{Cu}, \mathrm{Mn}, \mathrm{Ni}, \mathrm{Pb}, \mathrm{Sb}, \mathrm{Tl}$, and $\mathrm{W}$ ) and in addition sulfur for which samples of the basic material and blends after granulation were tested. The contents of individual elements are given in Tables 2 and 3. The tests were carried out using the ICP OES and ICP MS methods, after previous digestion in a microwave mineralizer, and the results are given in $\mathrm{mg} / \mathrm{kg}$ of dry matter. Only the tests for mercury content were carried out by means of the AAS method, using an AMA 254 spectrometer dedicated to mercury determination. The mercury contents in individual samples was determined in the analytical condition $\left(\mathrm{Hg}^{\mathrm{a}}\right)$. The moisture content of the 
TABLE 2. The content of the elements in the coal sludge and pulverized lignite used for research (before granulation)

TABELA 2. Zestawienie wyników badań składu chemicznego mułów węglowych oraz pyłów z węgla brunatnego wykorzystanych do badań (przed procesem granulowania)

\begin{tabular}{|c|c|c|c|c|c|}
\hline \multirow{2}{*}{ Marking } & \multicolumn{2}{|c|}{ Coal sludge } & \multicolumn{3}{c|}{ Pulverized lignite } \\
\cline { 2 - 6 } & Sludge 1 & Sludge 2 & Dust 1 & Dust 2 & Dust 3 \\
\hline S [\%] & 0.53 & 0.46 & 0.62 & 0.56 & 0.65 \\
\hline PN-EN ISO 11885:2009 & & 0.1908 & 0.0902 & 0.0814 & 0.0683 \\
\hline $\mathrm{Hg}[\mathrm{mg} / \mathrm{kg}]^{*}$ & 0.1318 & 5.82 & 5.83 & 0.82 & 5.18 \\
\hline $\mathrm{As}[\mathrm{mg} / \mathrm{kg}]$ & 10.80 & 0.75 & $<0.03$ & 0.01 & 0.02 \\
\hline $\mathrm{Cd}[\mathrm{mg} / \mathrm{kg}]$ & 0.07 & 80.85 & 4.77 & 3.08 & 1.92 \\
\hline $\mathrm{Cr}[\mathrm{mg} / \mathrm{kg}]$ & 63.78 & 12.38 & 0.32 & 0.34 & 0.28 \\
\hline $\mathrm{Co}[\mathrm{mg} / \mathrm{kg}]$ & 18.11 & 38.52 & 1.78 & 2.12 & 1.17 \\
\hline $\mathrm{Cu}[\mathrm{mg} / \mathrm{kg}]$ & 40.27 & 182.70 & 133.70 & 127.63 & 129.21 \\
\hline $\mathrm{Mn}[\mathrm{mg} / \mathrm{kg}]$ & 176.00 & 34.77 & 1.20 & 1.92 & 1.34 \\
\hline $\mathrm{Ni}[\mathrm{mg} / \mathrm{kg}]$ & 53.53 & 18.85 & 0.98 & 0.68 & 0.84 \\
\hline $\mathrm{Pb}[\mathrm{mg} / \mathrm{kg}]$ & 35.66 & - & 3.87 & - & - \\
\hline $\mathrm{Sb}[\mathrm{mg} / \mathrm{kg}]$ & - & 0.76 & 0.03 & 0.01 & 0.01 \\
\hline $\mathrm{Tl}[\mathrm{mg} / \mathrm{kg}]$ & 0.45 & 0.04 & 0.08 & 0.05 & 0.05 \\
\hline $\mathrm{W}[\mathrm{mg} / \mathrm{kg}]$ & 0.09 & & & & \\
\hline
\end{tabular}

Origin of the material: coal sludge - PG SILESIA; pulverized lignite - LEAG.

The tests were carried out using the ICP OES and ICP MS methods after digestion in a microwave mineralizer.

* Analysis performed in the air-dry condition (moisture content of samples $1.5-2 \%$ ) by the AAS method in an AMA 254 analyzer.

,-" Not marked.

Coal sludge 1 - sampling February 2018 (results acc. to Klojzy-Karczmarczyk et al. 2018).

Coal sludge 2 - sampling March 2019; pulverized lignite - sampling March 2019.

samples was determined as approx. $1.5-2 \%$. At such a low moisture content value it is possible to assume that the mercury content in the analytical condition is close to the mercury content in the dry condition $\left(\mathrm{Hg}^{\mathrm{d}}\right)$. The tests were carried out after granulation for consecutive quality parameters such as calorific value, ash content, volatile matter content, and additionally sulfur (in accordance with another determination method) in working conditions, according to normalized methods given in the table, and then they were converted into the dry condition. The results are specified in Table 4 . 


\subsection{Analysis of test results}

The results of total sulfur content determined by two different methods show slightly different values. In general, the results obtained by the PN-G-04584:2001 method for samples after granulation are slightly higher than the results obtained by the PN-EN ISO 11885:2009 method. This is related only to the specific nature of the determination method and not to granulation. The obtained results of tests for sulfur content $\left(\mathrm{S}_{\text {tot }}{ }^{\mathrm{d}}\right)$ for coal sludge samples range between 0.46 and $0.53 \% \%$, and after granulation the value determined for sludge samples is $0.53-0.67 \% \%$. The total sulfur content in the analyzed pulverized lignite $\left(\mathrm{S}_{\text {tot }}{ }^{\mathrm{d}}\right)$ is at the level of $0.56-0.65 \% \%$. The average value of the measurements made for lignite dust is $0.61 \% \%$. This is a value close to that given by the producer, as a long-term average value (https://www.lignoplus.de/). In general, the pulverized lignite of the LEAG company shows a low sulfur contents. it is also possible to find pulverized lignite on the market from companies other than LEAG with a definitely higher total sulfur content (https://www.epcoaltrading.cz/pl/). In the field of the other determinations of selected components considered toxic, the pulverized lignite shows comparable or lower values against the coal sludge (Table 2). The analyzed coal sludge features definitely higher chromium, copper, and nickel contents. On the basis of the conducted analysis it is possible to conclude that the admixture of pulverized lignite will not cause an increase in individual toxic elements contents in the blends samples.

The obtained results of tests for granulated samples of coal sludge and pulverized lignite blends were compared with the results obtained for coal sludge samples (sample 7 and $7 \mathrm{a}$ ). The carried out tests show that in relation to coal sludge (sulfur content of approx. $0.5 \%$ ) the applied pulverized lignite shows comparable sulfur contents. So its impact on this parameter increase has not been observed and the total sulfur content in granulated blends ranges from 0.48 to $0.56 \%$. At the applied percentage share of individual substrates in granulated blends samples (1:1) no increase in the analyzed toxic components content has been observed (Table 3). As compared with the coal sludge sample, an increase in individual components in blends samples is occasional and it is possible to state that the pulverized lignite addition does not have a significant impact on the total content of individual toxic elements and of sulfur in samples. The addition of $\mathrm{CaO}(3 \%)$ as a binder does not affect the contents of analyzed elements.

The quality requirements for solid fuels like: hard coal, briquettes, or pellets containing at least $85 \%$ of hard coal and products in a solid form obtained in the process of hard coal or lignite thermal processing intended for combustion were determined in the Regulation of the Minister of Energy dated September 272018 on Quality Requirements for Solid Fuels (Journal of Law 2018, item 1890). The document does not stipulate the quality requirements for the remaining solid fuels analyzed in this study, like coal sludge and pulverized lignite. Nevertheless, for comparative purposes, it is possible to compare the obtained test results with values stated in this document. In particular, quality parameters for solid fuels have been compared in terms of the ash content, total sulfur content, calorific value, and total moisture content (annex to the regulation-Tables 1 to 9). Such quality parameters determined for the analyzed samples are compared 
TABLE 3. The content of the selected toxic elements in samples subjected to laboratory tests (after granulation)

TABELA 3. Zestawienie zawartości wybranych pierwiastków toksycznych w próbkach wykorzystanych do badań laboratoryjnych (po granulowaniu)

\begin{tabular}{|c|c|c|c|c|c|c|c|}
\hline \multirow[b]{2}{*}{ Marking } & \multicolumn{7}{|c|}{ Samples } \\
\hline & $\begin{array}{c}1 \\
\text { sludge } 1 \\
+ \text { dust } 1\end{array}$ & $\begin{array}{c}2 \\
\text { sludge } 2 \\
+ \text { dust } 1 \\
\end{array}$ & $\begin{array}{c}3 \\
\text { sludge } 1 \\
+ \text { dust } 2 \\
\end{array}$ & $\begin{array}{c}4 \\
\text { sludge } 2 \\
+ \text { dust } 2\end{array}$ & $\begin{array}{c}5 \\
\text { sludge } 1 \\
+ \text { dust } 3 \\
\end{array}$ & $\begin{array}{c}6 \\
\text { sludge } 2 \\
+ \text { dust } 3 \\
\end{array}$ & $\begin{array}{c}7 \\
\text { sludge } 2\end{array}$ \\
\hline $\begin{array}{c}\text { S [\%] } \\
\text { PN-EN ISO } \\
\text { 11885:2009 }\end{array}$ & 0.50 & 0.55 & 0.51 & 0.51 & 0.56 & 0.48 & 0.53 \\
\hline $\mathrm{Hg}[\mathrm{mg} / \mathrm{kg}]^{*}$ & 0.1422 & 0.1533 & 0.1287 & 0.1188 & 0.1027 & 0.1229 & 0.1832 \\
\hline As $[\mathrm{mg} / \mathrm{kg}]$ & 4.58 & 3.06 & 3.72 & 3.66 & 7.01 & 4.90 & 5.69 \\
\hline $\mathrm{Cd}[\mathrm{mg} / \mathrm{kg}]$ & 0.10 & 0.07 & 0.10 & 0.07 & 0.03 & 0.08 & 0.09 \\
\hline $\mathrm{Cr}[\mathrm{mg} / \mathrm{kg}]$ & 51.06 & 44.71 & 39.46 & 43.45 & 33.64 & 52.35 & 65.45 \\
\hline $\mathrm{Co}[\mathrm{mg} / \mathrm{kg}]$ & 8.58 & 6.51 & 7.17 & 6.90 & 7.48 & 8.38 & 10.52 \\
\hline $\mathrm{Cu}[\mathrm{mg} / \mathrm{kg}]$ & 26.67 & 23.53 & 24.15 & 21.20 & 18.89 & 27.46 & 37.62 \\
\hline $\mathrm{Mn}[\mathrm{mg} / \mathrm{kg}]$ & 168.42 & 147.52 & 149.00 & 154.70 & 145.31 & 165.16 & 161.38 \\
\hline $\mathrm{Ni}[\mathrm{mg} / \mathrm{kg}]$ & 23.61 & 19.32 & 20.56 & 19.51 & 19.76 & 24.17 & 30.78 \\
\hline $\mathrm{Pb}[\mathrm{mg} / \mathrm{kg}]$ & 16.61 & 10.91 & 10.44 & 11.41 & 14.85 & 15.02 & 18.24 \\
\hline $\mathrm{Tl}[\mathrm{mg} / \mathrm{kg}]$ & 0.42 & 0.39 & 0.31 & 0.35 & 0.34 & 0.42 & 0.58 \\
\hline $\mathrm{W}[\mathrm{mg} / \mathrm{kg}]$ & 0.02 & 0.02 & 0.03 & 0.01 & 0.01 & 0.02 & 0.02 \\
\hline
\end{tabular}

The tests were carried out by the ICP OES and ICP MS methods after digestion in a microwave mineralizer.

* Analysis performed in the air-dry condition (moisture content of samples 1.5-2\%) by the AAS method in an AMA 254 analyzer.

An increase in the content as against sample 7 is marked in grey.

in Table 4. It should be emphasized that the material analyzed in the paper, due to the introduced legislation, can be used only in the commercial power sector.

The moisture content is a significant indicator of the fuel quality and affects the technological issues of the combustion. For the studied granulated samples of sludge with pulverized lignite the total moisture content $\left(\mathrm{W}^{\mathrm{r}}\right)$ in blends is approx. 6.0-8.5\%, and with the $\mathrm{CaO}$ addition 6.1-9.1\%. The ash content $\left(\mathrm{A}^{\mathrm{r}}\right)$ in coal sludge blends with pulverized lignite ranges between 29.2 and $40.4 \%$. In samples enriched with the binder the ash content in blends amounts to $30.4-44.4 \%$. The total sulfur content $\left(\mathrm{S}_{\text {tot }}{ }^{\mathrm{r}}\right)$ in samples of sludge and pulverized lignite blends falls within a range of $0.60-0.66 \%$, and in samples with the binder addition within $0.58-0.63 \%$. It should be emphasized that the tests carried out using the same samples by the ICP OES (PN -EN ISO 11885:2009) method have shown slightly lower values (Table 3). No change of this element content in granulates has been observed in samples of coal sludge. These values in general meet the requirements set for solid fuels in accordance with the Regulation of the Minister of Energy of 2018 (Journal of Law 2018, item 1890), but they cannot be used in the municipal sector due to restrictions resulting from the amendment to the Act of July 5, 2018 (Journal of Law 2018, item 1654). 
The calorific value or the heat of combustion are the overriding parameters determining the waste or by-products usefulness for power purposes. The calorific value of coal sludge falls within a range of 9.4-12.0 MJ/kg (as received), and after conversion into the dry basis it increases to $11.0-12.4 \mathrm{MJ} / \mathrm{kg}$. In the case of prepared coal sludge and pulverized lignite blends the calorific value clearly increases (Fig. 1, Table 4) to values 13.9-16.2 MJ/kg (as received), and after conversion into the dry basis gives values of $14.8-17.7 \mathrm{MJ} / \mathrm{kg}$. In each case the calorific value slightly falls after granulation with the $\mathrm{CaO}$ addition (Fig. 1). Such obtained values of blends increase the possibilities of application in the commercial power sector. For comparison it should be stated that the calorific value of hard coal itself is $24.5-33.8 \mathrm{MJ} / \mathrm{kg}$, while that of lignite $21 \mathrm{MJ} / \mathrm{kg}$ (http://www.instalacjebudowlane.pl). The calorific value of blends obtained based on coal sludge and pulverized lignite with a higher sulfur content of approx. $1.5 \%$ is within a range of $14.0-$ $-14.5 \mathrm{MJ} / \mathrm{kg}$ (as received), which converted into the dry basis gives values of $14.9-15.8 \mathrm{MJ} / \mathrm{kg}$ (Klojzy-Karczmarczyk et al. 2018).

TABLE 4. The quality parameters of samples for laboratory analysis (after granulation)

TABELA 4. Parametry jakościowe próbek wykorzystanych do badań laboratoryjnych (po granulowaniu)

\begin{tabular}{|c|c|c|c|c|c|c|c|}
\hline \multirow[b]{2}{*}{ Marking } & \multicolumn{7}{|c|}{ Samples } \\
\hline & $\begin{array}{c}1 \\
\text { sludge } 1 \\
+ \text { dust } 1\end{array}$ & $\begin{array}{c}2 \\
\text { sludge } 2 \\
+ \text { dust } 1\end{array}$ & $\begin{array}{c}3 \\
\text { sludge } 1 \\
+ \text { dust } 2\end{array}$ & $\begin{array}{c}4 \\
\text { sludge } 2 \\
+ \text { dust } 2\end{array}$ & $\begin{array}{c}5 \\
\text { sludge } 1 \\
+ \text { dust } 3\end{array}$ & $\begin{array}{c}6 \\
\text { sludge } 2 \\
+ \text { dust } 3\end{array}$ & $\begin{array}{c}7 \\
\text { sludge } 2\end{array}$ \\
\hline $\begin{array}{c}\text { The calorific value } \\
\mathrm{Q}^{\mathrm{r}}{ }^{\mathrm{L}}[\mathrm{kJ} / \mathrm{kg}] \\
\text { PN-81/G-04513 }\end{array}$ & 15900 & 15610 & 15991 & 14067 & 16232 & 13903 & 12041 \\
\hline $\begin{array}{c}\text { The calorific value } \\
\mathrm{Q}_{\mathrm{i}}{ }^{\mathrm{d}}[\mathrm{kJ} / \mathrm{kg}] \\
\text { dry basis }{ }^{*}\end{array}$ & 17152 & 17060 & 17325 & 14965 & 17682 & 14854 & 12388 \\
\hline $\begin{array}{l}\text { The ash content } \\
\qquad \mathrm{A}^{\mathrm{r}}[\%] \\
\text { PN-80/G-04512 } \\
+\mathrm{Az} 1: 2002\end{array}$ & 32.4 & 32.0 & 31.2 & 40.4 & 29.2 & 40.0 & 54.6 \\
\hline $\begin{array}{c}\text { The total sulfur } \\
\text { content } \mathrm{S}_{\text {tot }}{ }^{r}[\%] \\
\text { PN-G-04584:2001 }\end{array}$ & 0.66 & 0.66 & 0.64 & 0.61 & 0.66 & 0.60 & 0.65 \\
\hline $\begin{array}{l}\text { The total sulfur } \\
\text { content } \mathrm{S}_{\text {tot }}{ }^{\mathrm{d}}[\%] \\
\text { dry basis* }\end{array}$ & 0.71 & 0.72 & 0.69 & 0.65 & 0.72 & 0.64 & 0.67 \\
\hline $\begin{array}{c}\text { The total moisture } \\
\text { content } \mathrm{W}^{\mathrm{r}}[\%] \\
\mathrm{PN}-80 / \mathrm{G}-04511 \\
(\mathrm{p}, 2,3,1)\end{array}$ & 7.3 & 8.5 & 7.7 & 6.0 & 8.2 & 6.4 & 2.8 \\
\hline
\end{tabular}

$\mathrm{r}$ - as received, $\mathrm{d}$ - dry basis.

Tests carried out by Chemical Laboratory of PG Silesia Sp. z o.o.

* Converted to a dry basis: $\frac{1}{1-W^{r}}$. 


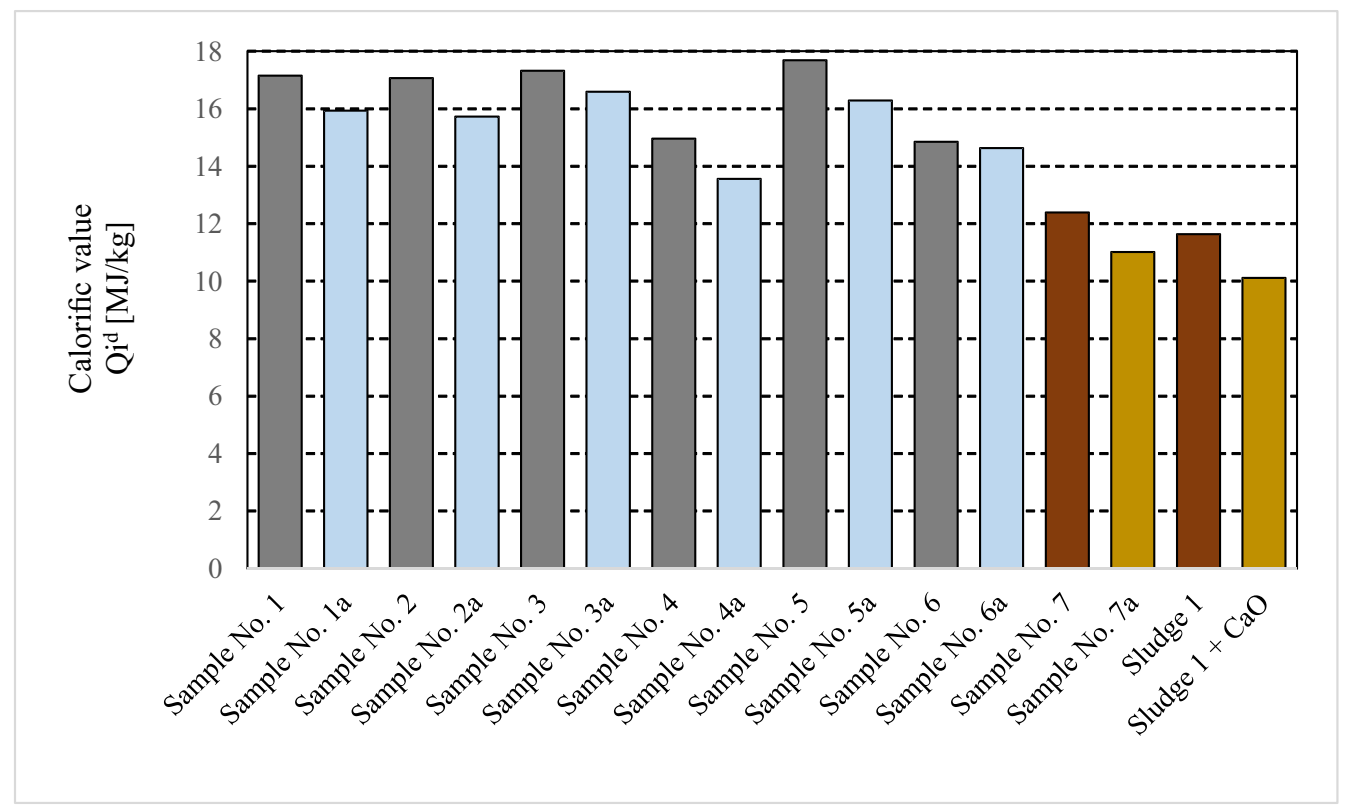

Fig. 1. Specification of calorific values of analyzed granulated blends of coal sludge with pulverized lignite (Sludge 1 sample acc. to Klojzy-Karczmarczyk et al. 2018)

Rys. 1. Zestawienie wartości opałowej analizowanych zgranulowanych mieszanek mułów węglowych z pyłami węglowymi węgla brunatnego

\section{Coal sludge and its blends granulation}

\subsection{Methodology}

The tests were carried out to determine possibilities and effects of coal sludge with pulverized lignite granulations to improve its transport possibilities with simultaneous improvement to its energy parameters. The tests of quality parameters presented above (section 2) were carried out for samples after granulation in a vibrating granulator designed at the AGH (Banaszewski et al. 2001; Banaszewski 1994). A detailed description of the granulation methodology for blends considered is provided in the paper by J. Feliks. B. Klojzy-Karczmarczyk. and M. Wiencek (Feliks et al. 2018). The parameters of granulator operation were set based on the previous experience (Feliks 2009). The amount of fed water was adjusted during granulation. After obtaining the satisfactory effect of granulation (approx. 50-100 s) a cleaning screw feeder was started, which 
transported the material to a tray. Then a few pellets approx. $12 \mathrm{~mm}$ in diameter were taken for drop strength testing. Tests were carried out immediately after granulation $(20 \mathrm{~min}$.) and the drop height was $500 \mathrm{~mm}$. The next stage of testing consisted in the determination of grain size composition, which was made after seasoning in approx. 24 hours (Fig. 2). After samples drying $(48 \mathrm{~h})$ the drop strength tests were carried out again, also from $500 \mathrm{~mm}$. Drops were made for five pellets and then their average strength was calculated, given in Table 5. Tests with values significantly deviating from the average were neglected in calculations.

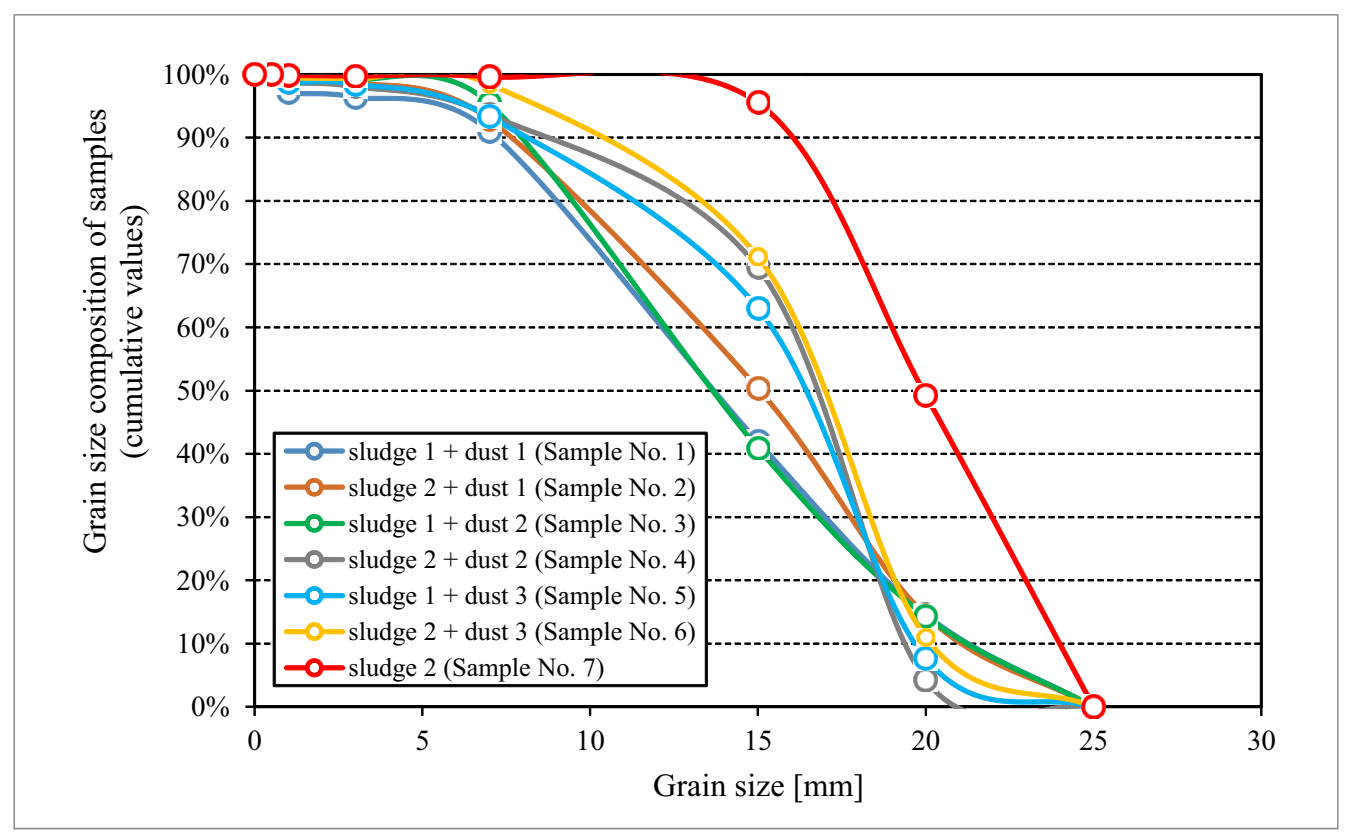

Fig. 2. Grain size compositions of coal sludge with pulverized lignite blends samples after granulation on a pipe vibration granulator

Rys. 2. Składy ziarnowe próbek mieszanek mułów węglowych z pyłami węglowymi węgla brunatnego po granulowaniu na rynnowym grudkowniku wibracyjnym

\subsection{Results and analysis}

Vibration granulation allows pellets to be obtained from each of the studied materials, both of coal sludge and of coal sludge blends with pulverized lignite. Prior to the palletization, the material with the $\mathrm{CaO}$ addition required drying at approx. $20^{\circ} \mathrm{C}$ during 24 hours to obtain a moisture content of approx. $30 \mathrm{wt} . \%$. To obtain a comparable grain size composition for samples of blends without the $\mathrm{CaO}$ addition, drying for another 24 hours was necessary. Basic tests consisted in the determination of granulation possibilities for blends of coal sludge with pulverized lignite (sam- 
TABLE 5. The resistance of granulated samples to drop

TABELA 5. Odporność zgranulowanych próbek na zrzuty

\begin{tabular}{|c|c|c|c|c|c|c|}
\hline \multirow{3}{*}{ Materials } & \multicolumn{3}{|c|}{ The samples without $\mathrm{CaO}$} & \multicolumn{3}{|c|}{ The samples with $\mathrm{CaO}(3 \%)$} \\
\hline & \multirow[t]{2}{*}{ samples } & \multicolumn{2}{|c|}{$\begin{array}{l}\text { the arithmetic mean } \\
\text { of the number of drops } \\
\text { (height } 500 \mathrm{~mm} \text { ) }\end{array}$} & \multirow[t]{2}{*}{ samples } & \multicolumn{2}{|c|}{$\begin{array}{l}\text { the arithmetic mean } \\
\text { of the number of drops } \\
\text { (height } 500 \mathrm{~mm} \text { ) }\end{array}$} \\
\hline & & after $20 \mathrm{~min}$. & after $48 \mathrm{~h}$ & & after $20 \mathrm{~min}$. & after $48 \mathrm{~h}$ \\
\hline sludge $1+$ dust 1 & 1 & 3.0 & 1.0 & 1a & 3.0 & 2.7 \\
\hline sludge $2+$ dust 1 & 2 & 4.0 & 3.3 & $2 \mathrm{a}$ & 4.0 & 1.0 \\
\hline sludge $1+$ dust 2 & 3 & 4.0 & 2.0 & $3 a$ & 4.0 & 1.0 \\
\hline sludge $2+$ dust 2 & 4 & 3.7 & 2.0 & $4 \mathrm{a}$ & 4.0 & 1.7 \\
\hline sludge $1+$ dust 3 & 5 & 5.0 & 2.0 & $5 \mathrm{a}$ & 6.0 & 2.0 \\
\hline sludge $2+$ dust 3 & 6 & 3.3 & 3.3 & $6 \mathrm{a}$ & 3.3 & 1.7 \\
\hline sludge 2 & 7 & 10.3 & 12.3 & $7 a$ & 14.7 & 12.0 \\
\hline
\end{tabular}

ples 1 to 6$)$. A binder was applied for better strength of the samples - burnt lime $(\mathrm{CaO})$. The grain size compositions of samples after granulation (without $\mathrm{CaO}$ ), after seasoning for approx. 24 hours, are presented in the graph (Fig. 2). Pellets obtained from pure coal sludge, at a comparable amount of moisture content of the feed, feature larger diameters. Pellets with diameters ranging between 2 and $20 \mathrm{~mm}$ in the product of blends vibration granulation constitute at least $82 \%$. In the case of pure sludge palletization, at comparable conditions of feed preparation, a large amount (approx. 50\%) of pellets originated with diameters exceeding $20 \mathrm{~mm}$. It is possible to obtain pellets of comparable parameters by a reduction of the feed moisture content (a longer drying time). Comparable test results were obtained in the case of $\mathrm{CaO}$ addition (samples 1a to 7a).

Pellets made of coal sludge without pulverized lignite addition feature the highest drop strength for drops from $500 \mathrm{~mm}$ (Table 5). Fresh sludge pellets subjected to drop tests from $500 \mathrm{~mm}$ after 20 minutes from the process completion withstood 10 to 11 drops. For samples with the $\mathrm{CaO}$ addition the number of drops grows to $14-15$. After 48 hours of seasoning the number of drops for coal sludge samples is $8-16$, and in the case of granulation with $\mathrm{CaO}$ this number is $11-13$.

The product in the form of pellets, obtained as a result of blending and granulating coal sludge with pulverized lignite at a proportion of 1:1, shows a much better drop strength (average values are presented in Table 5). For a fresh material without the $\mathrm{CaO}$ addition, the number of drops from $500 \mathrm{~mm}$ ranges from 2 to 6 after 20 minutes from the completed granulation. For samples with the binder addition the number of drops is from 2 to 7 . After the material seasoning $(48 \mathrm{~h})$ the strength of pellets approx. $12 \mathrm{~mm}$ in diameter goes down, on average by $30 \%$. For a fresh material without the $\mathrm{CaO}$ addition, the number of drops from $500 \mathrm{~mm}$ ranges from 1 to 4. For samples with the binder addition the number of drops is 1 to 3 . So no favorable impact of $\mathrm{CaO}$ presence on pellets strength after granulation and seasoning is observed. 
As compared with the granulation effects of coal sludge with pulverized lignite of increased sulfur content of approx. 1.5\% (Feliks et al. 2018), it has been found that the pellets drop strength is lower in the analyzed case of blends with coal dusts of sulfur content of approx. $0.6 \%$. So the transport possibilities of the produced material are worse. Similar tests carried out for blends of coal sludge, but with pulverized lignite of higher sulfur content. have shown that fresh pellets withstood approx. 10 drops and no significant differences with respect to this parameter have been noticed. After a longer period of seasoning the number of drops from $500 \mathrm{~mm}$ decreases to $4-6$, on average 4.8 (without a binder) and 4.2 (with carbonates addition). The differences result most likely from the mineralogical composition of the analyzed samples and this can be the subject of subsequent studies.

\section{Summary and conclusions}

Coal sludge is an inseparable by-product of hard coal production, frequently featuring a low calorific value. It is classified as waste with code 010412 and 010481 or it is a by-product in the production of a raw material with limited energy importance. Instead, pulverized lignite is a final product of drying and next very fine pulverization of lignite with a high calorific value. It is necessary to look for new solutions to manage both materials.

Studies have been undertaken to show parameter changes by making coal sludge blends (PG SILESIA) with pulverized lignite of low sulfur content (LEAG) in relation to the original material, which is the coal sludge. The basic study comprised the basic materials before granulation: coal sludge and pulverized lignite as well as prepared blends of coal sludge with pulverized lignite and a binder after the granulation on a vibration pelletizer designed by AGH. The study was aimed at finding a way to increase the attractiveness of coal sludge, as a fuel for commercial customers, by increasing their calorific value as a result of blending with pulverized lignite and improvement in their transport properties. The obtained results were compared with the study carried out by the paper authors in 2018 based on coal sludge of the same origin and pulverized lignite, but with a higher sulfur content (no producer identification) (Klojzy-Karczmarczyk et al. 2018; Feliks et al. 2018). The carried out studies have shown that as a result of blending coal sludge with pulverized lignite and of such material granulating it is possible to manufacture a product of appropriate quality and physical parameters with a clear improvement in energy parameters.

In general, the pulverized lignite of the LEAG company shows low sulfur contents. In the analyzed samples its average content $\left(\mathrm{S}_{\text {tot }}{ }^{\mathrm{d}}\right)$ is $0.61 \%$. An average value of this parameter in the analyzed coal sludge samples measured by various testing methods is $0.55 \%$. The carried out studies show that in comparison with the coal sludge itself, granulates made of sludge and pulverized lignite with the $\mathrm{CaO}$ addition or without a binder feature an averaged total sulfur content of approx. $0.50 \%$. Slightly different results of sulfur content are observed in the case of various te- 
sting methods application for the same samples. It is possible to state that the addition of pulverized lignite does not have a significant impact on the total content of analyzed toxic elements $(\mathrm{Hg}$, $\mathrm{As}, \mathrm{Cd}, \mathrm{Cr}, \mathrm{Co}, \mathrm{Cu}, \mathrm{Mn}, \mathrm{Ni}, \mathrm{Pb}, \mathrm{Sb}, \mathrm{Tl}$, and $\mathrm{W}$ ) and of sulfur in samples. The addition of $\mathrm{CaO}$ (at the amount of $3 \%$ ) as a binder does not substantially affect the contents of the analyzed elements.

The calorific value of coal sludge falls within a range of 9.4-12.0 MJ/kg (as received) and after converting to the dry basis it increases to $11.0-12.4 \mathrm{MJ} / \mathrm{kg}$. The calorific value slightly decreases in the case of granulation with the $\mathrm{CaO}$ addition. In the case of prepared coal sludge and pulverized lignite blends the calorific value clearly increases to values of $13.9-16.2 \mathrm{MJ} / \mathrm{kg}$ (as received) and after conversion to the dry basis gives values of $14.8-17.7 \mathrm{MJ} / \mathrm{kg}$. Such values increase the application possibilities in the commercial power sector. Prepared blends may be used in plants with rated thermal power not less than $1 \mathrm{MW}$.

After the process of granulation carried out under laboratory conditions, it is possible to state that all sludge and pulverized lignite blends are susceptible to granulation. The granulation itself undoubtedly widens the transport possibilities of coal sludge itself as well as of its blends. The grain size composition of the obtained material is satisfactory. Pellets with diameters ranging between 2 and $20 \mathrm{~mm}$ in the product of blends vibration granulation constitute at least $82 \%$. Pellets obtained from pure coal sludge, at a comparable amount of moisture content of the feed, feature larger diameters.

The drop strength of fresh pellets (20 minutes after granulation completion) is satisfactory. The arithmetic mean of the number of drops is 3.8 (for samples without $\mathrm{CaO}$ ) and 4.0 (for samples with $\mathrm{CaO}$ ). However, after 48 hours of seasoning from the granulation completion the drop strength of blends definitely decreases and it has an arithmetic mean of 2.3 and 1.7, respectively. Based on that it is possible to conclude that the addition of a binder in such blends is not necessary and does not contribute to the expected effect. The strength of pellets approx. $12 \mathrm{~mm}$ in diameter after seasoning goes down by $30 \%$, except for pellets made of pure coal sludge. Pellets made of coal sludge without pulverized lignite addition show the highest drop strength, reaching from 8 to 16 drops from $500 \mathrm{~mm}$. As compared with the granulation effects of coal sludge with pulverized lignite of increased sulfur content of approx. $1.5 \%$, it has been found that in the analyzed case of blends with coal dusts of sulfur content of approx. $0.6 \%$ of the pellets drop strength is definitely lower. So the transport possibilities of the produced material are worse at the assumed percentage share of basic components.

No cost analysis of the analyzed project has been carried out. It is possible to conclude from the study performed that the undertaken topic is promising and that premises to continue it exist. A significant issue consists in a change of substrates, a change of tests performance conditions, and the determination of optimum shares of individual components of the prospective product.

The study was carried out under the statutory work of the Mineral and Energy Economy Research Institute, Polish Academy of Sciences and under the statutory work of the Department of Machinery Engineering and Transport of AGH in Kraków. 


\section{References}

[Online] http://www.instalacjebudowlane.pl - Energy value of coal, gas, oil and other fuels (Wartość energetyczna węgla, gazu, oleju i innych paliw) [Accessed: 2018-07-23] (in Polish).

[Online] https://www.epcoaltrading.cz/pl/produkty/pyl-wegla-brunatnego/ - The pulverized lignite (Pyt węgla brunatnego) [Accessed: 2019-07-21] (in Polish).

[Online] https://www.lignoplus.de/pyl-wegla-brunatnego.php - LignoPlus. A strong fuel alternative from refined lignite (Silna alternatywa paliwowa z uszlachetnionego wegla brunatnego) [Accessed: 201907-21] (in Polish).

BANASZEWSKI et al. 2001 - BANASZEWSKi, T., KobiaŁKA, R., BARAn, J., FiliPOWICZ, A. and FeliKs, J. 2001. Novel vale vibratory pelleter (Wibracyjny grudkownik rynnowy). PL 350979 Polska, 30112001 (in Polish).

BANASZEWSKI, T. 1994. Vibration balling (Grudkownik wibracyjny). Patent PL no. 173892 Polska, 2111994.

BIELOwICZ, B. 2013. Selected harmful elements in Polish lignite (Wystepowanie wybranych pierwiastków szkodliwych w polskim węglu brunatnym). Gospodarka Surowcami Mineralnymi-Mineral Resources Management Vol. 29, Issue 3, pp. 47-59 (in Polish).

FELIKS, J. 2009. The simulation of pellets motion in the novel vale vibratory pelleter (Badania symulacyjne ruchu grudek w rynnowym grudkowniku wibracyjnym dla różnych średnic rynny). Inżynieria i Aparatura Chemiczna Vol. R. 48, No. 4, pp. 38-39 (in Polish).

FELIKS J. et al. 2018 - FeliKs, J., KLOJZY-KARCZMARCZYK, B. and WIENCEK, M. 2018. Granulating coal sludge and their mixtures to improve transport properties (Granulowanie mutów węglowych i ich mieszanek celem poprawy właściwości transportowych). Zeszyty Naukowe Instytutu Gospodarki Surowcami Mineralnymi i Energia Polskiej Akademii Nauk No. 104, pp. 173-188 (in Polish).

Journal of Law 2018, item 1654. Act of 5 July 2018. Amending the law on monitoring and control of fuel quality and the Act on the National Tax Administration (Ustawa $z$ dnia 5 lipca 2018 r. o zmianie ustawy o systemie monitorowania i kontrolowania jakości paliw oraz ustawy o Krajowej Administracji Skarbowej) (Dz.U. z 2018, poz. 1654) (in Polish).

Journal of Law 2018, item 1890. Regulation of the Minister of Energy of 27 September 2018, concerning the quality requirements for solid fuels (Rozporzadzenie Ministra Energii z dnia 27 września 2018 roku w sprawie wymagań jakościowych dla paliw statych) (Dz.U. z 2018, poz. 1890) (in Polish).

KLOJZY-KARCZMARCZYK at al. 2018 - KLOJZY-KARCZMARCZYK, B., MAZUREK, J. and WIENCEK, M. 2018. Coal sludge and their mixtures as prospective energy resources. Polityka Energetyczna - Energy Policy Journal Vol. 21, Issue 3, pp. 137-15.

KloJZy-KarCZMARCZYK, B. and MAZureK, J. 2017. Proposals to extend actions to the management of waste rock from hard coal mining (Propozycje rozszerzenia działań celem zagospodarowania materiałów odpadowych z górnictwa węgla kamiennego). Zeszyty Naukowe Instytutu Gospodarki Surowcami Mineralnymi i Energia Polskiej Akademii Nauk No. 98, pp. 151-165.

MakowsKa i in. 2017 - MakowsKa, D., Wierońska, F., Dziok, T. and StrugaŁa, A. 2017. Ecotoxic elements emission from the combustion of solid fuels due to legal regulations (Emisja pierwiastków ekotoksycznych z procesów spalania paliw stałych w świetle regulacji prawnych). Polityka Energetyczna-Energy Policy Journal Vol. 20, Issue 4, pp. 89-102 (in Polish).

Stala-SzlugaJ, K. 2018a. The Anti-Smog Resolutions in Poland and Their Impact on Hard Coal Consumption in Households (Uchwaty antysmogowe w Polsce a ich oddziatywanie na zużcie węgla kamiennego w gospodarstwach domowych). Journal of the Polish Mineral Engineering Society No. 2, pp. 161-168 (in Polish).

Stala-Szlugaj, K. 2018b. Hard coal demand for households in Poland vs. Anti-smog law. Archives of Mining Sciences Vol. 63, Issue 3, pp. 701-711. 


\title{
Mieszanki mułów węgla kamiennego z pyłami węgla brunatnego jako alternatywne surowce energetyczne
}

\author{
Streszczenie
}

Muły węgla kamiennego klasyfikowane są jako odpady z grupy 01 lub są ubocznym produktem w produkcji surowca, często o niskiej wartości opałowej. Pył węgla brunatnego nie jest odpadem, ale produktem wyjściowym suszenia i bardzo drobnego mielenia węgla brunatnego o wysokiej wartości opałowej. W pracy badaniami objęto materiał podstawowy przed procesem granulowania, czyli muły węglowe (PG SILESIA) i pył węgla brunatnego (LEAG) oraz ich mieszanki po procesie granulowania na grudkowniku wibracyjnym konstrukcji AGH. Pyły węgla brunatnego firmy LEAG wykazują niskie zawartości siarki. Jej średnia zawartość $\mathrm{w}$ analizowanych próbkach $\left(\mathrm{S}_{\mathrm{tot}}{ }^{\mathrm{d}}\right)$ wynosi $0,61 \%$. Średnia wielkość tego parametru $\mathrm{w}$ analizowanych mułach węglowych wynosi $0,52 \%$. Dodatek pyłu węgla brunatnego nie ma znaczącego wpływu na całkowitą zawartość w próbkach siarki oraz analizowanych pierwiastków toksycznych (Hg, As, $\mathrm{Cd}, \mathrm{Cr}, \mathrm{Co}, \mathrm{Cu}, \mathrm{Mn}, \mathrm{Ni}, \mathrm{Pb}, \mathrm{Sb}, \mathrm{Tl}, \mathrm{W})$. Wartość opałowa mułów węglowych mieści się w granicach 11,0-12,4 MJ/kg (w stanie suchym). Dla mieszanin mułu węglowego z pyłami węgla brunatnego wartość opałowa zdecydowanie wzrasta do wielkości 14,8-17,7 MJ/kg (w stanie suchym). Obserwuje się nieznaczne obniżenie wartości opałowej w przypadku granulowania z dodatkiem $\mathrm{CaO}$. Takie wartości zwiększają możliwości zastosowania w energetyce zawodowej. Wszystkie mieszanki mułów z pyłami węgla brunatnego są podatne na proces grudkowania (granulowania). Wytrzymałość na zrzuty grudek świeżych jest zadawalająca, a wartość uśredniona kształtuje się na poziomie 4. Po sezonowaniu próbek odporność na zrzuty mieszanek zdecydowanie maleje, średnio o $30 \%$ z wyjątkiem grudek wykonanych z czystego mułu węglowego. Dodatek analizowanych pyłów węgla brunatnego utrudnia zatem procesy grudkowania w stosunku do czystych mułów węglowych.

SŁOWA KLUCZOWE: muły węglowe (węgla kamiennego), pyły węgla brunatnego, granulowanie (grudkowanie), parametry jakościowe, wartość opałowa 
